\title{
COMPLEMENTARY ACTIVITY OF THE BLOOD IN RHEUMATISM AND CERTAIN ALLIED DISORDERS
}

BY

\author{
C. E. KELLETT \\ Newcastle General Hospital
}

(RECEIVED FOR PUBLICATION MARCH 30, 1954)

In the study of rheumatic fever there has been, as Fischel, Pauli, and Lesh (1949) remark, "disagreement and confusion as to the level of serum complement'. Though Weil and Buchholz (1932) and Coburn (1936) have reported a low complement of the serum, rising to normal with the subsidence of activity, both these authors and Hadjopoulos and Burbank (1928) noted high values during the early period of rheumatic activity and low values later. It was formerly thought (Kellett, 1936) that, in certain cases, the onset of the disease was associated with a low level of complement in the blood, but, whereas in acute nephritis this fall seemed to be related to the onset of acute glomerulonephritis, no such clear relationship was discerned in the rheumatic cases. Recently, however, the opportunity has occurred of repeating this work on a larger scale, making use of methods better calculated to give accurate results, and it is with these that this paper is concerned.

\section{Method}

Burroughs Wellcome sheep cells were used throughout and sensitized with the Burroughs Wellcome haemolytic serum (glycerinated) for sheep corpuscles. Instead of ordinary saline, Brook's modified saline was used; this was made up as follows:

$\begin{array}{lr}\mathrm{NaCl} & 170 \mathrm{~g} . \\ \mathrm{KH}_{2} \mathrm{PO}_{4} & 2.78 \mathrm{~g} .\end{array}$

$\mathrm{NA}_{2} \mathrm{HPO}_{4} \quad 11 \cdot 3$ g. (equivalent to $\mathrm{NA}_{2} 12 \mathrm{H}_{2} \mathrm{O} 28 \cdot 5$ g.)

Distilled water to $1,000 \mathrm{ml}$.

This was kept as a stock solution and, before use, was diluted 1/20 with distilled water.

Exactly $5 \mathrm{ml}$. sheep blood cells were placed in a centri- fuge tube and washed three times in the modified saline solution and made up to the original quantity. These were added to $45 \mathrm{ml}$. modified saline, giving a 1/10 dilution of washed cells. $\quad 0.2 \mathrm{ml}$. haemolytic serum was added to $50 \mathrm{ml}$. modified saline, and, in this form, was mixed with the red blood cell suspension. The mixture was allowed to stand at room temperature for 15 minutes (immune body being present in slight excess). Each serum to be tested was drawn off a sample of blood, which had been allowed to clot and had been stored overnight in a refrigerator, and diluted $1 / 50$ in the modified saline. The test was set up as shown in the Table.

The tubes were placed in a water bath at $37^{\circ} \mathrm{C}$. for 45 minutes, and centrifuged; the amount of haemolysis in the supernatant fluid was determined on an E.E.L. colorimeter, and the result expressed in terms of percentage of total haemolysis.

In Figs 1 to 4 have been plotted the readings obtained by this method in certain different types of patients admitted to the wards during the 2 years when this investigation was proceeding. In each instance, where more than two estimations were carried out, the highest and lowest readings obtained have been recorded.

\section{Results}

It is apparent that, whereas the level of complementary activity varied within a relatively narrow range in a group of people complaining of stomach pain, regarded as a control group, this range of activity was far greater in cases of rheumatoid arthritis and rheumatism, and was, indeed, almost comparable to that encountered in acute nephritis; furthermore, though in certain instances it would

TABLE

METHOD OF SETTING UP TEST

\begin{tabular}{llll|l|l|l|l|l|l|l|l|l|l|l|l|l}
\hline Tubes & $\ldots$ & $\ldots$ & $\ldots$ & 1 & 2 & 3 & 4 & 5 & 6 & 7 & 8 & 9 & 10 & 11 \\
\hline Diluted human serum (ml.) & $\ldots$ & $5 \cdot 0$ & $4 \cdot 5$ & $4 \cdot 0$ & $3 \cdot 5$ & $3 \cdot 0$ & $2 \cdot 5$ & $2 \cdot 0$ & $1 \cdot 5$ & $1 \cdot 0$ & $0 \cdot 5$ & 0 \\
\hline Modified saline (ml.) & $\ldots$ & $\ldots$ & 0.5 & $1 \cdot 0$ & $1 \cdot 5$ & $2 \cdot 0$ & $2 \cdot 5$ & $3 \cdot 0$ & $3 \cdot 5$ & $4 \cdot 0$ & $4 \cdot 5$ & $5 \cdot 0$ & $5 \cdot 5$ \\
\hline Sensitized cells (ml.) & $\ldots$ & $\ldots$ & $2 \cdot 0$ & $2 \cdot 0$ & $2 \cdot 0$ & $2 \cdot 0$ & $2 \cdot 0$ & $2 \cdot 0$ & $2 \cdot 0$ & $2 \cdot 0$ & $2 \cdot 0$ & $2 \cdot 0$ & $2 \cdot 0$ \\
\hline
\end{tabular}


seem as if for a time complementary activity was enhanced, in a greater number of examples of abnormality, the activity was reduced. In the majority of cases encountered during this period, however, the disease had been present for a number of years, and, in these, the complementary activity of the blood seemed to rest within the normal range and did not vary with the blood sedimentation readings.

From these curves, moreover, it is possible in each instance to determine the amount of serum required to bring about a 50 per cent. haemolysis in the system employed. If this be considered a unit,

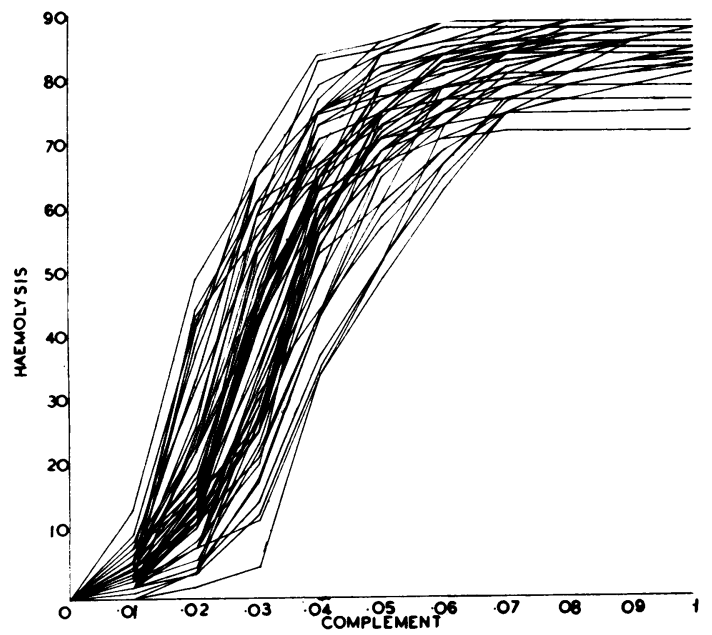

Fig. 1.-Changes in activity in gastric disorders.

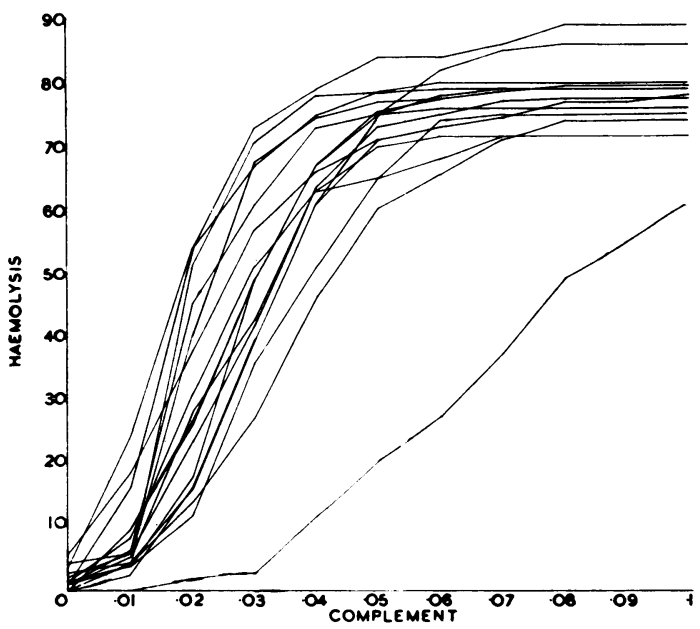

Fig. 3.-Changes in activity in rheumatic fever. then it may be convenient to express the activity of the serum in terms of the number of the units contained per $\mathrm{ml}$. Such a simplification would seem $\frac{\nabla}{\rho}$. legitimate, provided it be clearly understood that this measure refers, not to an absolute quantity but rather to an activity under certain reproducible $\overline{0}$ conditions. Figs 1 to 4 may then be said to show 흠 that, whereas the sera obtained in patients suffering $\frac{\bar{m}}{\frac{\bar{N}}{\sigma}}$ from gastric disorders contains 20 to 50 units $/ \mathrm{ml}$., $\stackrel{\mathbb{\perp}}{\propto}$ those from cases of rheumatoid arthritis contained from 0 to 67 units $/ \mathrm{ml}$., from rheumatic fever from 12 to 62 units $/ \mathrm{ml}$., and from nephritis from 0 to 50 ? units $/ \mathrm{ml}$.

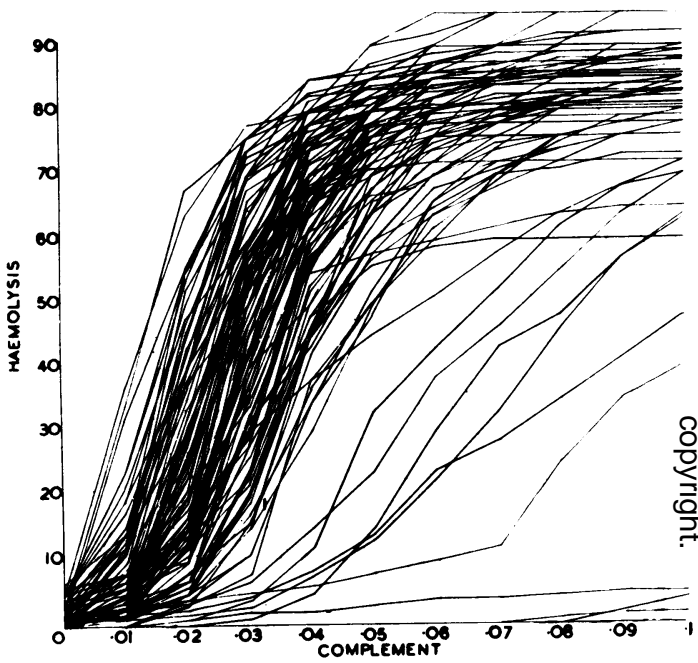

Fig. 2.-Changes in activity in rheumatoid arthritis, spondylitis, and lupus erythematosus.

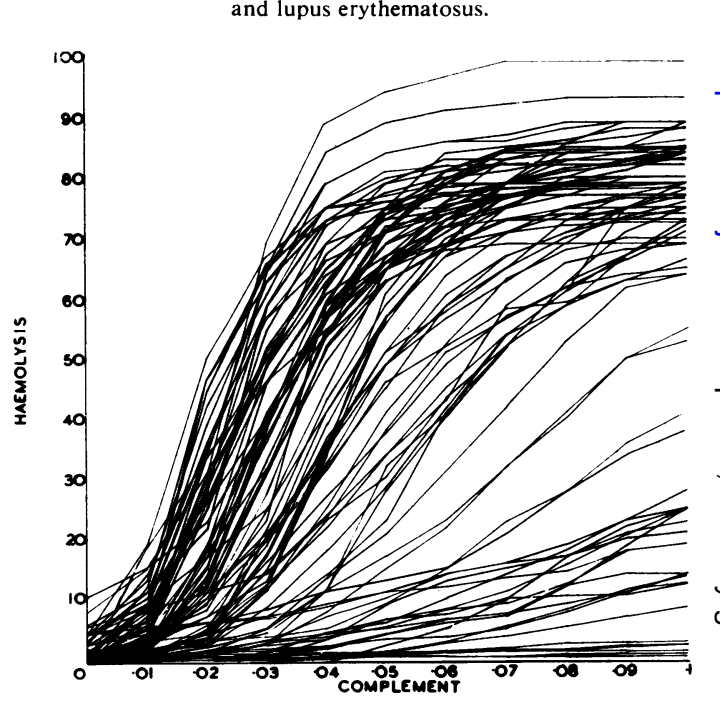

Fig. 4.-Changes in activity in nephritis.

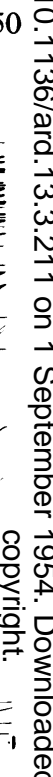

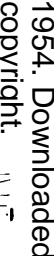

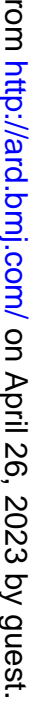

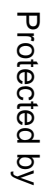


Rheumatic Fever.-Relatively few cases were encountered during the 2 years under review.

Fig. 5 summarizes the changes in Case 1, a girl aged 16, who had had a previous attack at the age of 6 but had remained free from further attacks until 3 weeks before admission. She then had severe tonsillitis, followed a fortnight later by pain and redness of the right knee; the majority of the other joints of her body were subsequently involved, but responded, within 24 hours of admission on October 20, 1951, to 20 gr. sodium salicylate three times a day. She was maintained on this for the next 2 months. During this time she was symptom free but developed signs of aortic incompetence, which have persisted up till the present.
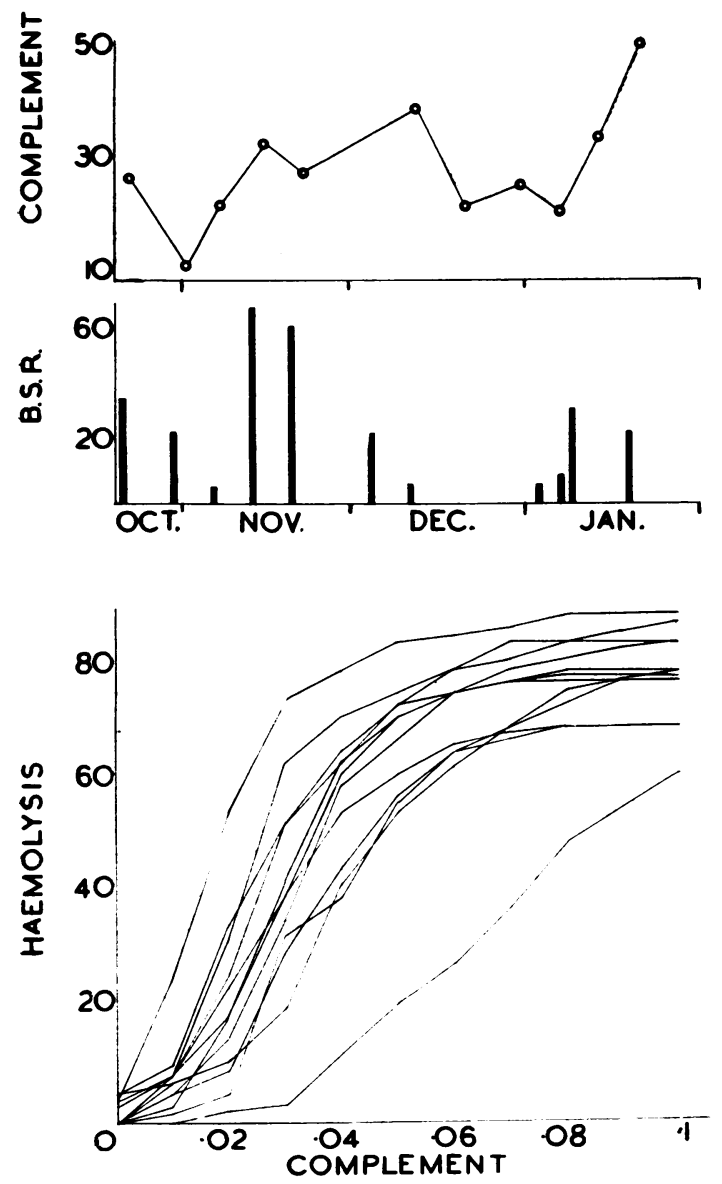

Fig. 5.-Case 1, girl aged 16, rheumatic fever.

Case 2 (Fig. 6), that of a boy aged 16, was under review for 3 months. This was his first attack; it followed a week after a severe sore throat, and was in this instance treated by a course of cortisone, which promptly relieved the symptoms but which, on cessation, was immediately followed by a relapse, so that he was given another course. He too developed aortic incompetence, and, 5 weeks after his last course was completed, profound mental changes, which have persisted.
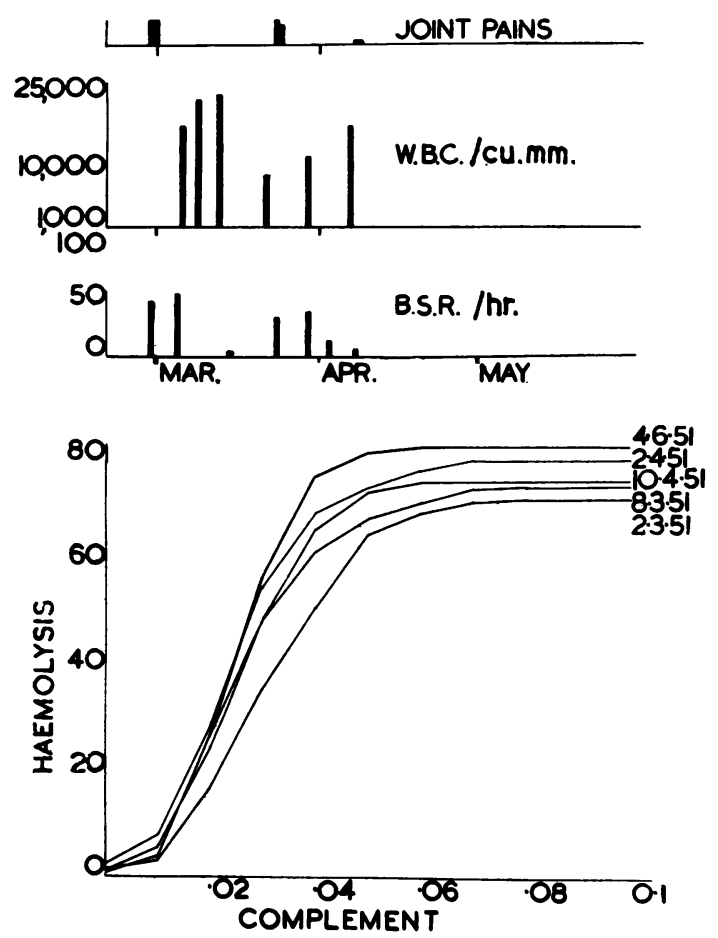

Fig. 6.-Case 2, boy aged 16, rheumatic fever.

In Case 1 the changes in complementary activity were slight and seemed to bear no relation to those in the blood sedimentation rate; in Case 2 there were no such changes. In both instances convalescence was marked by high levels.

Rheumatoid Arthritis.-Several cases were seen for a short time only, for the purpose of determining whether or not they were likely to benefit from a course of cortisone, so that though 79 cases were tested for complementary activity, 44 were only tested once and nineteen twice, the remainder being tested on three or many more occasions. In the first group (44 readings), 36 lay between 20 and 40 units $/ \mathrm{ml}$. with one below and seven above. In the second group (38 readings), 31 lay between 20 and 40 units $/ \mathrm{ml}$, with one below and six above. It would seem that isolated readings in the majority of cases of rheumatoid arthritis would lead to results well within the normal range. 


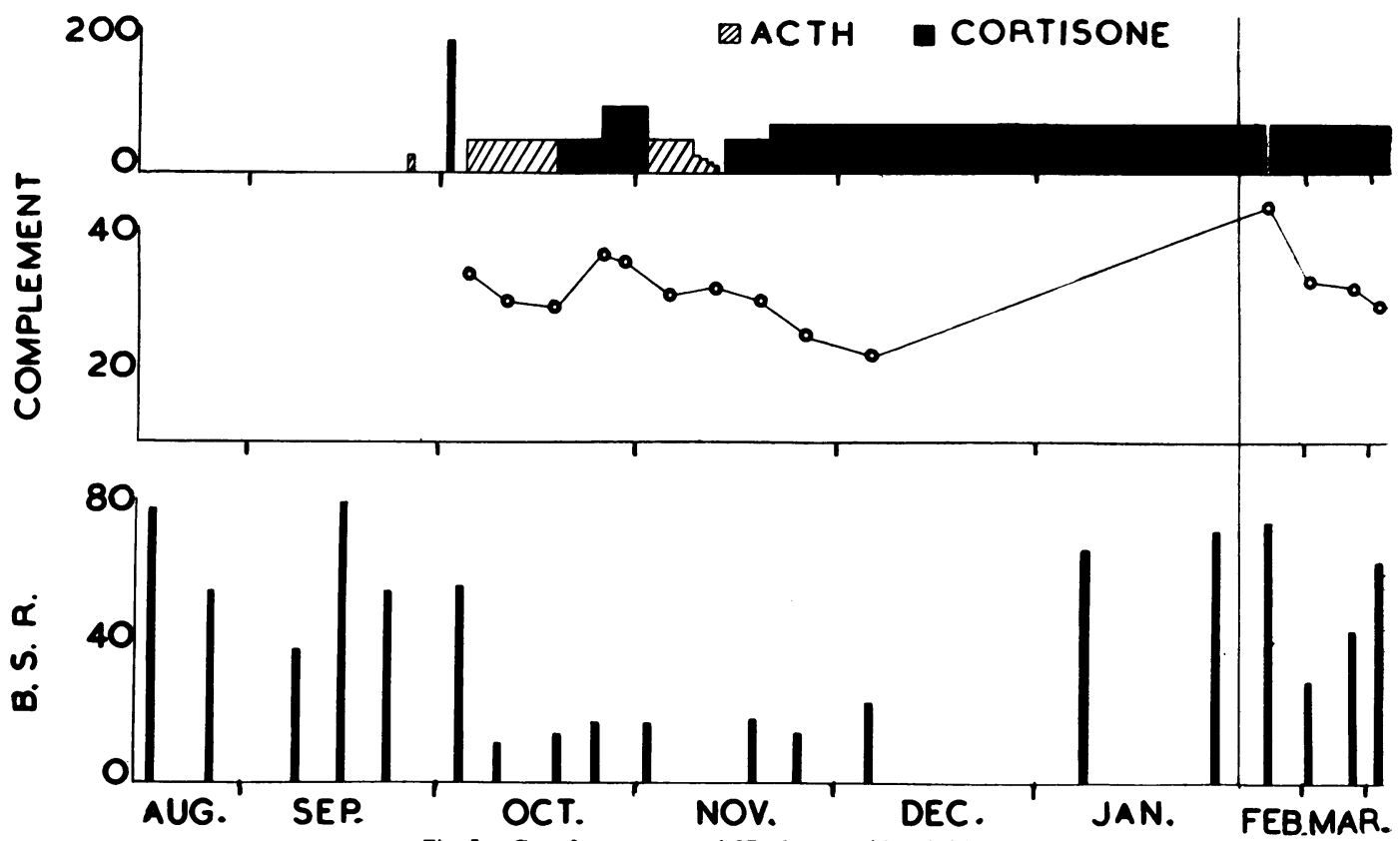

Fig. 7 -Case 3 , woman aged 37 , rheumatoid arthritis.
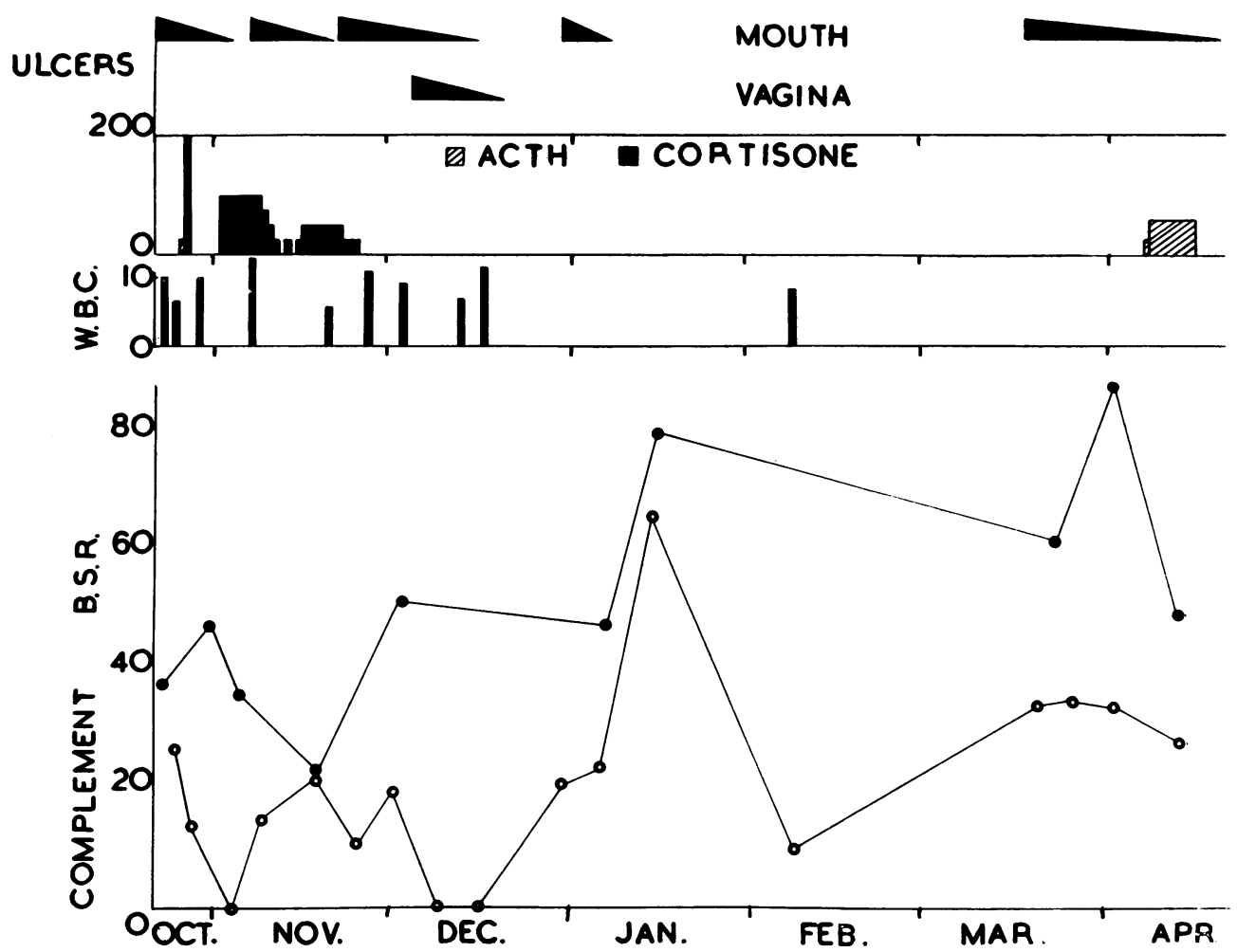

Fig. 8.-Case 4 , woman aged 29 , rheumatoid arthritis. 
Fig. 7 (opposite) summarizes the main changes seen in Case 3, a woman aged 37, with severe rheumatoid arthritis which had been progressive for the past 6 years, until all the joints had become involved. Though there had been a temporary response to courses of gold injections, radiant heat, and spa therapy, this patient had become almost crippled. She responded fairly well to cortisone and ACTH and was one of the few to be kept on permanent maintenance doses of these substances.

Fig. 8 (opposite) summarizes the findings in Case 4, a woman aged 29, with rheumatoid arthritis of 8 years' duration, which involved first the ankles and knees, and subsequently spread to the elbows. She had had psoriasis since childhood, and, while in hospital, developed multiple ulcers of the mouth and vagina, which were very resistant to treatment. It was thought possible that this might be a case of lupus erythematosus, but typical cells were not detected. There was no leukopenia and the
Wassermann reaction and gonococcal complementfixation test were negative. After 3 years she is in fairly good general condition, though she is gradually becoming more crippled by arthritis.

Lupus Erythematosus.-Only two proven cases were investigated during this period. In both the disease was associated with a marked fall in the complementary activity of the blood.

Fig. 9 summarizes the findings in Case 5, a woman aged 22, who was kept under observation for a number of years. She was first seen in September, 1946, when she appeared to have rheumatoid arthritis, which responded well to a course of gold treatment; 4 years later she was admitted with a pericardial effusion and was considered to be suffering from pericarditis, associated with active rheumatoid arthritis. She was re-admitted 3 months later, having had two further
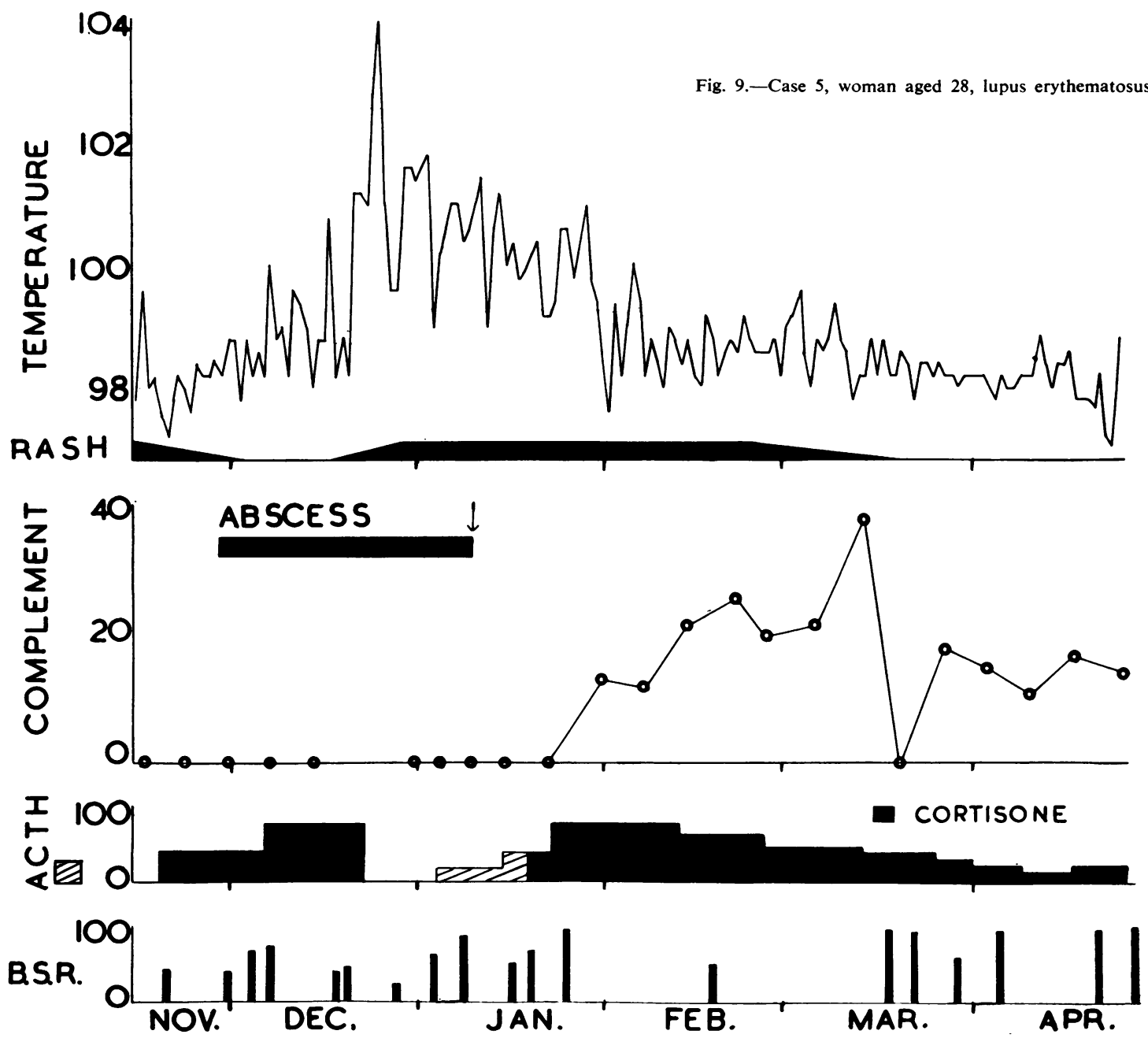
attacks of what appeared to be a diffuse rheumatic process associated with a skin rash, and lupus erythematosus involving her eyebrows, cheeks, and nose. Liver function tests and a skin biopsy were normal. A year later she was admitted with an exacerbation of her general condition and a diagnosis of disseminated lupus erythematosus established. She responded, to begin with, to cortisone, but her condition deteriorated and she died at the age of 28 on September 9, 1952. The most marked changes found at autopsy were in the kidneys, where there was a severe degree of glomerular damage, mostly in the form of fibrinoid necrosis in focal masses, sometimes involving nearly all the glomerulus.

Case 6 , a woman aged 29 , was seen by the author on only two occasions (Fig. 10). Her illness had begun with a swelling of the fingers and wrists, 4 months before admission, and had subsided after a period of rest, but had recurred. To begin with she again appeared to do fairly well with rest, but after the second month she developed a continuous fever, her spleen became palpable, and, 3 months after admission, extensive painful ulcers occurred in the mucous membrane of the mouth and palate. She did not respond either to penicillin, chloromycetin, or streptomycin. In addition she had recurrent rashes, with a loud systolic murmur, and
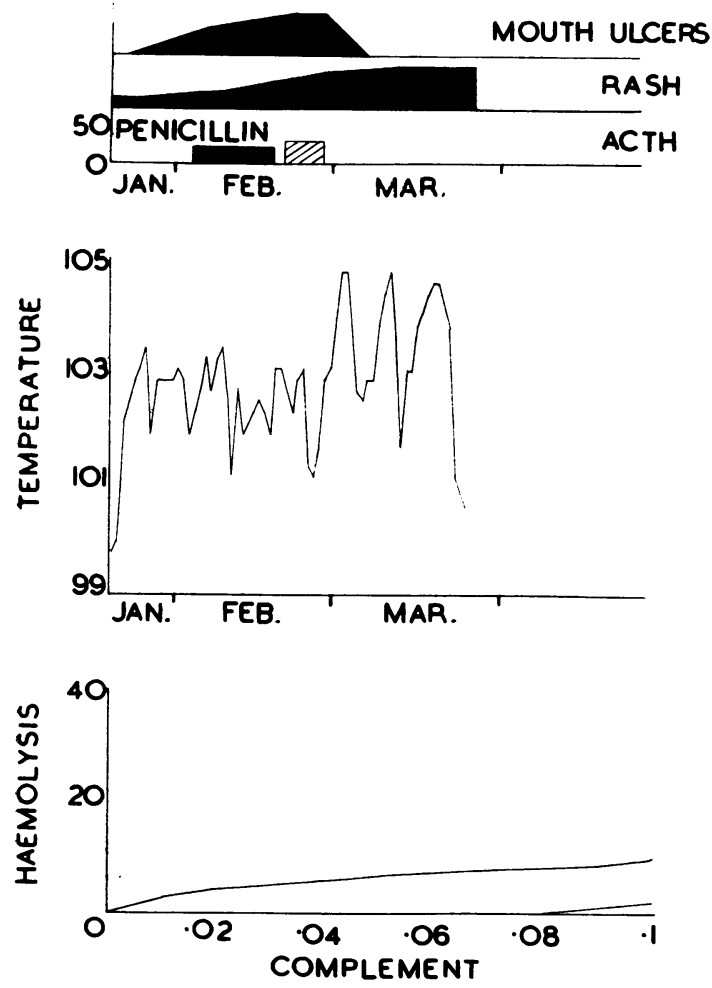

Fig. 10.-Case 6, woman aged 29, lupus erythematosus. signs of pleural involvement. She ultimately died, 7 months after admission, on March 26, 1952. A $\frac{5}{3}$ diagnosis of sub-acute lupus erythematosus was con- $\square$ firmed at autopsy.

In Cases 5 and 6 the changes in the complementary $\overrightarrow{\overrightarrow{0}}$ activity of the blood are more marked than in those -0 previously recorded, and it would be tempting to $\frac{}{0}$ believe that the extent of the fall was in some way linked up with the severity of the disease process.

Spondylitis. - The following case, however, empha- ڤે sizes the difficulties that arise once an attempt is $\overrightarrow{0}$ made to establish such a correlation.

Fig. 11 summarizes the findings in Case 7 , a young man aged 32, who had been perfectly well until 3 months before admission, when he had had an influenza-like? illness, which kept him in bed for 3 weeks. Shortly after $\vec{\omega}$ this, he developed such acute pain in the muscles of the back that he was unable to move and had to lie flat in $\rightarrow$ bed. At the age of 7 he had had chorea but had had $\overrightarrow{0}$ no rheumatism since then. His blood sedimentation rate on admission was $95 \mathrm{~mm}$./hr. $X$ rays of his spine and an $\vec{c}$ electrocardiogram were normal. The blood picture and $\mathbb{D}$ liver function tests were within normal limits. To begin $\frac{D}{\square}$

SERUM ALKALINE PHOSPHATASE 10.4 units/100 mb THYMOL TURBIDITY 3 Units; FLOCCULATION O
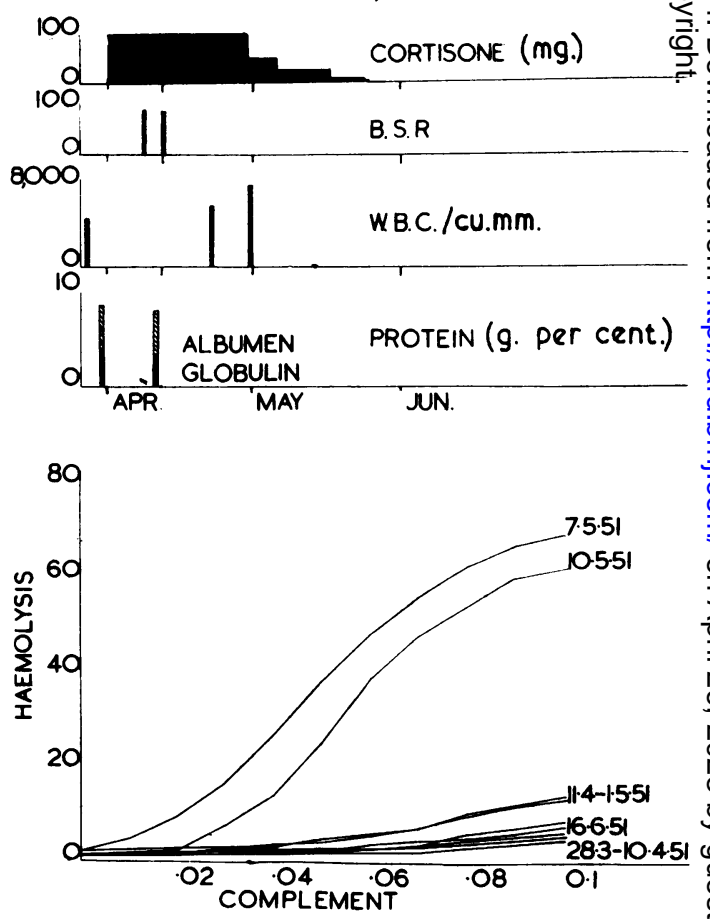

Fig. 11.-Case 7, man aged 32, spondylitis. 
with, he improved on salicylates but this improvement was of short duration, and he was, therefore, placed on cortisone, which resulted in a very dramatic change. He was able to sit up in bed, with a full range of movements, and felt so well that he ultimately discharged himself and returned to work. He managed fairly well for about a year, when his pains returned. He again became so bad that he had to give up work 4 months ago and was sent to hospital to see an orthopaedic surgeon. His blood sedimentation rate was found to be $85 \mathrm{~mm} . / \mathrm{hr}$, and a diagnosis of spondylitis was again made, although the radiologist reported no obvious changes in his spine. He has had a course of radiotherapy, but his back is still stiff and he is at present having physiotherapy.

\section{Discussion}

Waaler (1937) encountered serum from a case of rheumatoid arthritis which inhibited the haemolysis of sheep red cells and also caused marked agglutination of the same cells in the presence of a small amount of haemolytic amboceptor. While haemolytic amboceptor was used in slight excess throughout our experiments, and we did not, so far as we are aware, encounter this phenomenon of agglutination, it might well be urged, in a case such as this, that the initial fall in complementary activity was due either to the appearance of anti-complementary substances in such excess as to mask any subsequent recovery, or to a reaction such as that described by Waaler.

The simple experiment recorded in Fig. 12 would, however, suggest that this is not so. A sample of the Serum A, taken on the first occasion the patient was seen and found to be without complementary activity, was diluted $1 / 25$ instead of the routine $1 / 50$ and added to an equal quantity of a similar dilution of Serum B from another patient in whom the

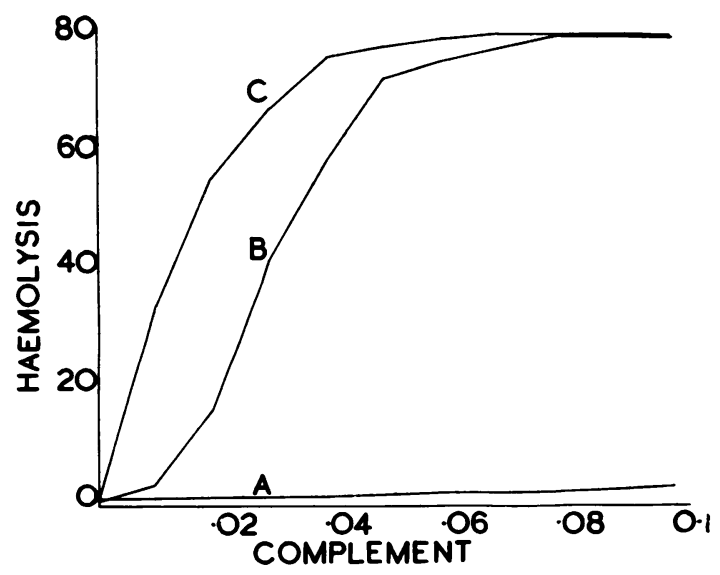

Fig. 12.-Experiment assessing two sera (A and $B$ ), and a mixture of the two $(C)$. complementary activity was depressed to within the lower limits of normality. Having been allowed to stand for 30 minutes at room temperature, the activity of the mixture containing each serum in the routine dilution of $1 / 50$ was assessed by the method employed throughout this work (c). As in similar experiments carried out in cases of nephritis, the complementary activity of the mixture was the greater, implying the absence of anti-complementary substance in excess or of any effect similar to that described by Waaler.

Nevertheless, there does appear to be an inverse relationship between our findings and those of workers carrying out the test based on this effect. Alexander and de Forest (1954) found it to be negative in just those conditions in which we found complement most diminished (namely: lupus erythematosus, arthritis with psoriasis, and ankylosing spondylitis), and positive in the majority of cases of rheumatoid arthritis, in which we found little change in the complementary activity of the blood. It would seem, therefore, that, if there is a relationship between these agglutinins of the blood and the diminished complementary activity, it is one which could perhaps be best explained on the assumption that both the agglutinins and complement had become used up in some form of reaction, and it may well be that further study of these changes along such lines, might prove of value.

The work of these 2 years has, unfortunately, done little to dispel the disagreement and confusion referred to at the beginning of this paper. The method employed may tend to make a rise in complementary activity of the blood less obvious than a fall, but, so far as our findings are concerned, this fall would appear to be a more striking phenomenon than the rise referred to by Fischell, Pauli, and Lesh (1949), and it may well prove to be a significant finding in cases of lupus erythematosus. Such changes can hardly be devoid of meaning, and it would seem that further study of this phenomenon may well be worth while.

\section{Summary}

There is at present no general agreement as to the changes in the complementary activity of the blood that may occur in rheumatoid arthritis and certain apparently allied conditions, such as ankylosing spondylitis, arthritis with psoriasis, and lupus erythematosus. Rather marked variations of activity are, however, encountered, particularly in the last three conditions, in which activity may be greatly impaired, and it is, perhaps, significant that Waaler's reaction, in a recent series by Alexander and De Forest, proved in these to be negative. 
It is a pleasure to have this opportunity of thanking Miss G. Partington and Miss A. Stickland, my technical assistants, who carried out the complementary estimations; my colleagues, for their ready co-operation; and the Newcastle-upon-Tyne Regional Hospital Board for the research grant which made this work possible.

\section{REFERENCES}

Alexander, R., and de Forest, G. K. (1954). Amer. J. Med., 16, 191. Coburn, A. F. (1936). Lancet, 2, 1025

Fischel, E. E., Pauli, R. H., and Lesh, J. (1949). J. clin. Invest., 28, 1172 .

Hadjopoulos, L. G., and Burbank, R. (1928). J. Lab. clin. Med., 14,131

Kellett, C. E. (1936). Lancet, 2, 1262.

(1952). Ibid., 2, 911.

Veil, W. H., and Buchholz, B. (1932). Klin. Wschr., 11, 2019.

Waaler, E. (1940). Acta path. microbiol. scand., 17, 172.

Activité du complément sanguin dans le rhumatisme et dans certaines affections apparentées

\section{RÉsUMÉ}

A présent il n'y a pas d'accord général sur les variations de l'activité du complément sanguin pouvant survenir dans l'arthrite rhumatismale et dans certaines affections apparentées, telles que la spondylarthrite ankylosante, l'arthrite psoriasique et le lupus érythémateux. Des variations sssez prononcées, cependant, se rencontrent, surtout dans les trois dernières affections, dans lesquelles cette activité peut être considérablement affaiblie, et il semble significatif que, selon les expériences récentes d'Alexander et de De Forest, la réaction de Waaler y soit négative.

Actividad del complemento sanguíneo en el reumatismo y en algunos disturbios aliados

\section{SUMARIO}

No existe al presente acuerdo general respecto a variaciones de la actividad del complemento sanguíneo susceptibles de producírse en la artritis reumatoide y en algunas afecciones aliadas, como la espondilartritis anquilosante, la artritis con soriasis y el lupus eritematoso. Encuéntranse, sin embargo, variaciones bastante pronunciadas, particularmente en las tres últimas afecciones en las cuales puede haber considerable disminución de esta actividad; parece significativo que, según la experiencia reciente de Alexander y de De Forest, la reacción de Waaler fuera negativa en estos disturbios. 